\title{
Exchange Rate Impacts on Investment of Manufacturing Sectors in Iran
}

\author{
Mohammad Reza Lotfalipour \\ Professor of Economics, Department of Economics, Ferdowsi University of Mashhad \\ E-mail: lotfalipour@um.ac.ir
}

Maliheh Ashena

Ph. D student, Faculty of Economics, Tarbiat Modares University

E-mail:m.ashena@modares.ac.ir

Maryam Zabihi

M.A. in Economics, Ferdowsi University of Mashhad

E-mail:m.zabihi20@yahoo.com

Received: May 23, 2013 Accepted: June 3, 2013

doi:10.5296/ber.v3i2.3716

URL: http://dx.doi.org/10.5296/ber.v3i2.3716

\begin{abstract}
As a major factor in the development process and economic policies evaluation, investment and its growth rate have been considered in many studies. This paper examines the relationship between changes in exchange rate and the investment of manufacturing sectors in Iran during1995 to 2009 using the panel data approach. So, the annual data of manufacturing sectors is used to examine the impact of real exchange rate fluctuations on industrial investment. It is found a negative and statistically significant impact of real exchange rate movements on manufacturing investment.
\end{abstract}

Keywords: Manufacturing sectors, Exchange rate, Panel Data, Iran.

JEL Classification: D51, E22, L52. 


\section{Introduction}

As a major factor in the development process and economic policies evaluation, investment and its growth rate have been considered in many studies. Most of the previous studies introduce increasing investment as the only way to reduce unemployment and increase productivity. Iran as a developing economy is located in the course of economic growth and has determined prospects of economic advancement. In order to meet the economic development needs and to achieve progress of these measures, some necessary and effective tools must be taken. This is achieved through the study of economic behavior, as well as social and geography conditions of the society.

Investment in the industry sector is affected by factors such as value added, the amount of banking facilities, costs of capital, crude oil revenue, exchange rate and economic growth. Problems such as strong reliance on the oil revenues for buying machinery and raw materials, the dominant role of government in economic management, shortage of liquidity, lack of linkage between planning and executing of industrial development needs, exacerbates the problems of the industry.

The increase of the secondary sector products and shift of resources from the primary to the secondary sector may be considered as a driver of the development process. The manufactured export increases income more than the primary products (Hausmann et al., 2005).

Over the past two decades many developed and developing countries have experienced Changes in exchange rate. Baldwin and Krugman (1989) pointed the durable effects of major exchange rates changes on international trade.

The economic approaches to exchange rate management have evolved over the past decades. For adjusting an economy there are some instruments such as exchange rate that it has to be considered in response to changes in factors affecting a country's economic equilibrium.

The implications of exchange rate changes for the economy have been focused of empirical studies in international economics. These studies examined the impact of exchange rate increase or decrease on macroeconomic key factors.

Although there have been substantial currency fluctuations over the recent years, few studies have been focused on examining exchange rate movements and manufacturing sector. This paper investigates the relationship between exchange rate changes and the manufacturing sector investment in Iran.

The paper is organized in four Sections. Section 2 summarizes theoretical framework and reviews literature. Section 3 explains the methodology and empirical results. Section 4 represent conclusion.

\section{Review of Literature}

There are some theoretical arguments underlying the stimulating role of manufacturing sector for economic development. The increase of the secondary sector products and moving resources from the primary to the secondary sector may be considered as a driver of the 
development process.

Investment is a determinant factor of output level, productivity and growth. Changes in exchange rate may cause changes in the profitability of production and investment incentives. Exchange rate increase may increase the demand of domestic products and the cost of imported capital and other imported inputs. It will cause investment increase only if the impact on demand is more than the cost effect.

There are some factors affecting the optimal response of an industry investment policy to exchange rate changes. It includes the reliance on imported inputs and the share of foreign sales in total sales. If a firm is more dependent on imported inputs, there will be more variable costs and less marginal value of capital. So a depreciation of exchange rate causes a reduction in the level of industrial investment. By contrast, there will be increase in price competitiveness a firm following an exchange rate appreciation. This is likely leads to an increase in the expected value of capital and its level of investment.

Those sectors, in which output price is determined in the world markets, are likely to be more sensitive to exchange rate movements. The manufacturing firms that rely on export and imported inputs, the effect of currency valuation changes could be either positive or negative.

The choice of control variables is a crucial aspect of any empirical study of investment. Demand-side explanatory variables (such as sales or output) and cost factors (such as the user cost of capital or the price of oil) were employed by most studies.

Any changes in exchange rate has set of conflicting changes in foreign and domestic economy so that its result can be positive or negative. Upcoming opportunities of liberalization of the exchange rate in the industrial sector can be summarized as follows:

a. An increase in the exchange rate causes moving towards higher value-added products. The point where is considered as a threat of exchange rate liberalization, may have $a$ key role in the industrial development of the country.

b. Iran's industry has the ability to produce foreign goods of the same quality. The liberalization of exchange rates removes the need of high tariff walls for supporting of domestic products.

c. In recent years, many activities have done in order to reduce waste and unnecessary costs. These removal costs and damages of industries cannot be overlooked. The lliberalization of the exchange rate will follow decreasing waste and managing costs.

On the other hand, profitability is the most important factor of the private investment in the industry sector. Increase of industry sector profitability will have the greatest impact on investment of private sector. Profitability in the non-manufacturing and the speculation sectors of the economy in some cases is also associated with various rents. Therefore, the owners of capital will tend to invest in the non-manufacturing sectors that have more profitability, less risk and more power of transferring the capital. Due to these issues, the exchange policy is one of the policies affecting investment decisions. The exchange rate changes may affect investment through increasing exports and increasing prices of imported capital goods and raw materials. In addition, the feature of irreversibility and the delay of investment make investing 
decisions more sensitive to the real exchange rate fluctuations.

Developing countries, including Iran have experienced large fluctuations in their macroeconomic variables such as growth, inflation, and exchange rates. The effects of these fluctuations have discussed in various studies of growth, investment and trade.

The wage has important role in determination of investment while the wage itself is affected by government expenditure policy. Alesina et al. (2002) presented evidence of a relationship between investment and government expenditure, and between wages and government expenditures.

The exchange rate has two opposing effects on manufacturing sales (both to the domestic and the international markets). Based on the Krugman's (1979) model and modified model from Fung (2008), a depreciation of the home currency gives domestic industries a cost advantage and their sales will rise. Afterward, entry of new firms may reduce the market share. It is more likely that exports increases following home currency depreciation, but its effect on domestic sales may be ambiguous, depending on the importance of new firm's entry. If there is increasing returns to scale of production technology, productivity will move in the same direction as total sales. Thus, the direction and magnitude of changes in exports and domestic sales will affect not only total sales but also productivity and investment (Fung and Liu, 2009).

Some studies explored exchange rate and trade relation in terms of export or import (Bernard and Jensen (2004) and Landon and Smith (2007)). Nouria et al. (2011) showed that during the period 1991-2005 a number of countries have used undervaluation to foster the price competitiveness of manufactured exports.

There is considerable emphasis on the study of pricing policies in response to changes in exchange rate (Goldberg and Knetter, 1997). Some others study the impact of exchange rate movements on the firm value (Jorion (1990), Bodnar and Gentry (1993), Clarida (1997), and Bodnar, Dumas and Marston (1998), Harris (2001), Head and Ries (1999)).

The investigation of the exchange rate effects on investment decisions of manufacturing industries in Colombia has emphasized the negative impact of exchange rate fluctuations on the industrial sector (Kandilov and Leblebicioğlu, 2011). While studying industries investment in Canada during 1981-1997 shows that it is not affected by the exchange rate changes (Harchaoui, et al., 2005).

There are few researches focusing on the sensitivity of firms' investment to changes in the currency value (Goldberg (1993), Campa and Goldberg (1995), Campa and Goldberg (1999), Forbs, 2002 Serven (2003), Fuentes (2006)). As the first contribution, Goldberg (1993) indicates that currency appreciations led to different consequences on investment in various periods. Campa and Goldberg (1999) showed that an exchange rate increase leads to manufacturing investment decline in the US. Similarly, Forbes (2002) found that there is slower growth in capital investment following exchange rate increase in commodity firms with higher capital/ labour ratios.

Fung (2008) explored, both theoretically and empirically, the effects of the considerable 
appreciation of the Taiwanese currency, the New Taiwan dollar (the NT dollar), on both firm turnover and production scale. The results of Fung and Liu (2009) indicated that the real depreciation of the NT dollar led to an increase in exports, domestic sales, total sales, value-added, and productivity. In addition, they found that there may be productivity improvement induced by real currency depreciation a result of firm scale expansion.

Using an error correction methodology, the aggregate and sector-level investment equations for a panel of 17 OECD countries was estimated by Landon and Smith (2009). It is found that real currency depreciation may reduce aggregate investment and investment of nine sectors in the short run. Furthermore, it causes reduction of aggregate investment in the long run. Kandilov and Leblebicioğlu (2011) found a robust negative impact of exchange rate volatility on plant investment.

Researches employing the data of the Iranian Manufacturing sectors includes Arman and Ghorbani (2005), Lotfalipour and Razmara (2006), Khodaparast (2001) and ghetmiri (1996).

While there is some empirical literature on the impact of exchange rate on investment, there are only a few studies that have considered the manufacturing subsectors. Moreover, most of the studies are based on the data at the aggregated industry level. In this paper we analyze the relationship between investment and exchange rate fluctuations using industrial subsectors panel data.

\section{Methodology and Empirical Results}

The mentioned theoretical and empirical framework motivates studying investment and exchange rate relationship, and it also highlights some other important factors of this relationship. The goal of the paper is to estimate the impact of exchange rate changes on investment, so we estimate a reduced form investment equation. The following baseline dynamic specification (1) is estimated, which focuses on the main effect of exchange rate on investment.

$$
I=F(I(-1), E X R, W, V A)
$$

Where I is investment, EXR is exchange rate, $\mathrm{W}$ is real price of the non-tradable domestic input and VA is value-added.

The model is estimated based on dynamic panel data using the generalized method of moments estimator developed by Arellano and Bond (1991). In the considered equation, investment interacts with the relevant industry-specific and time-varying explanatory variables. Therefore, the estimated effect of the exchange rate on investment is allowed to vary over time for each industry.

Providing a large number of point data, panel data approach allows for more powerful statistical tests and normal distribution of test statistics. It can also take heterogeneity of each cross-sectional unit into account, and give "more variability, less collinearity among variables, more degrees of freedom, and more efficiency" (Baltagi, 2001). 


\subsection{Panel Data Unit Root Tests}

Studies on panel unit root tests include Hadri (2000), Maddala and Wu (1999), Levin et al. (2002), Im et al. (2003). Among different panel unit root tests developed in the literature, LLC test (Levin et al., 2002) and IPS test (Im et al., 2003) are the most popular and are based on the ADF principle. However, the LLC test assumes homogeneity in the dynamics of the autoregressive coefficients for all panel members. In contrast, the IPS test allows for heterogeneity in these dynamics. IPS begins by specifying a separate ADF regression for each cross section. The IPS test is based on the following model:

$$
\Delta y_{i t}=\alpha_{i}+\beta_{i} y_{i, t-1}+\sum_{j=1}^{p_{i}} \rho_{i j} \Delta y_{i, t-j}+\varepsilon_{i t}
$$

where $y_{i t}$ is the series for country $i$ in the panel over period $t, \rho_{i}$ is the number of lags selected for the ADF regression and $\varepsilon_{\text {it }}$ are independently and normally distributed random variables for all $i$ and $t$ with zero means and finite heterogeneous variances.

IPS tests the null hypothesis of the unit root for each individual in the panel, that is, $H_{0}: \beta_{i}=0, \nabla i$

LLC unit root test considers the coefficients of the autoregressive term as homogeneous across all individual. So, LLC tests the null hypothesis that each individual in the panel has integrated time series, that is

$$
H_{0}: \beta_{i}=\beta=0, \nabla i
$$

Maddalaand Wu's (1999) and Choi's (2001) tests were developed to overcome the shortcomings of the LLC and the IPS tests. They suggest panel unit root tests using a Fisher statistic. Table 1 presents the test results of the panel level series including a constant term and time trend.

\begin{tabular}{|c|c|c|c|c|}
\hline variables & LI & LEXR & LW & LVA \\
\hline Levin, Lin \& Chu t. & $-5.22(0.00)$ & $-6.41(0.00)$ & $-6.89(0.00)$ & $-10.27(0.00)$ \\
\hline Im, Pesaran\& Shin W-stat & $-2.19(0.01)$ & & $-1.91(0.02)$ & $-3.42(0.00)$ \\
\hline ADF - Fisher Chi-square & $72.68(0.00)$ & $79.84(0.00)$ & $68.05(0.02)$ & $87.84(0.00)$ \\
\hline $\mathrm{PP}$ - Fisher Chi-square & $147.53(0.00)$ & $150.65(0.00)$ & $92.75(0.00)$ & $95.50(0.00)$ \\
\hline
\end{tabular}

Table 1. Panel unit root test results

The results of IPS, LLC and Fisher tests indicate that the panel level series are stationary. Therefore, we have chosen to use the panel level series in the panel VAR analysis.

\subsection{Empirical Results}

In this section, the exchange rate effect on the investment of manufacturing sector is investigated empirically. As Iran experienced large currency depreciations in the recent years, it can be of great importance to policy makers to understand the exchange rate effects on industry sector performance. In this paper, we employ manufacturing sector panel data of Iran 
to examine the impact on the manufacturing subsectors investment of the substantial real depreciation of the exchange rate.

The empirical analysis has been conducted using data of 2-digit ISIC industries drawn from statistical yearbook during 1995-2008. The data include information on exchange rate, investment, domestic output and compensation of the non-tradable domestic input.

Employing industry-level data from the Iranian Manufacturing sector, we estimate a dynamic investment equation using the system-GMM estimator developed by Arellano and Bover (1995) and Blundell and Bond (1998).

The fixed effects in panel data permit us to account for heterogeneity of industries. Moreover, panel data allows us to study dynamics for the individual industries. Hence, by including both the individual-specific and the time-specific effects into the specification for panel data, a larger portion of the omitted-variable bias can be eliminated.

The real exchange rate, EXR, is measured as domestic currency units per unit of foreign currency. The theoretical investment equation includes real value-added, VA, and the real price of the non-tradable domestic input, W. Industry-specific fixed effects, $\mu$, are included in the estimating equation to represent the determinants of investment that differ across industries, but are constant through time. Incorporating the variables described above in the panel model, Eq. (3) yields the estimable investment equation:

$$
L I_{i t}=\alpha_{1}+\sum_{j=1}^{m} \beta_{1 j} L I_{i, t-j}+\sum_{j=1}^{m} \beta_{2 j} L V A_{i, t-j}+\sum_{j=1}^{m} \beta_{3 j} L W_{i, t-j}+\sum_{j=1}^{m} \beta_{4 j} L E X R_{i, t-j}+\mu_{1 i}+\varepsilon_{1 i t}
$$

Where $\mathrm{i}$ and $\mathrm{t}$ denote, respectively, industry $\mathrm{i}$ and time $\mathrm{t}, \mathrm{j}$ is the lag length, $\mu_{\mathrm{i}}$ is industry-specific effects and $\varepsilon_{i t}$ is the disturbance terms. If the coefficient $\beta \mathrm{i}$ in equation (3) is significantly different from zero, then that variable may be said to have impacts on investment.

This specification incorporates lags of investment, and the current value and some lags of all the explanatory variables. We treat all of the industry specific variables as endogenous, and use lagged values dated $\mathrm{t}-2$ as the GMM-type instruments.

The optimal lag length in the VAR model based on the Schwarz Information Criterion (SIC) is chosen two. Table 2 shows the results for estimating the model using GMM. The Sargan test is a test on whether the instruments are valid (uncorrelated with the error term).

Table 2. Estimation results of the panel regression

\begin{tabular}{|l|l|}
\hline Variables & LI \\
\hline LI(-1) & $-0.393(-4.617)$ \\
\hline LI(-2) & $-0.183(-3.987)$ \\
\hline LW & $0.691(1.827)$ \\
\hline LVA & $0.208(0.555)$ \\
\hline LEXR & $-0.568(-2.573)$ \\
\hline LVA(-1) & $0.313(5.456)$ \\
\hline LEXR(-1) & $0.474(1.779)$ \\
\hline Sargan test (p-level) & 9.35 \\
\hline Instrument rank & 20 \\
\hline
\end{tabular}

Figures in brackets denote t-statistics. 
Based on these results, we found a strong negative and statistically significant impact of real exchange rate movements on plant investment. Based on the theoretical expectations, we would expect exchange rate to have impact on investment and it is valid for selected industrial subsectors. The test results suggest that the null hypothesis of coefficients insignificance is rejected. It indicates that exchange rate and investment lags have negative and significant impact. Since the real exchange rate is indicated as an indicator of competitiveness of domestic goods relative to foreign goods, therefore fluctuations in the exchange rate reduce desire of producers to investment.This result demonstrates that real depreciation of the home currency has unfavorable effects on investment of industry sector. In terms of control variables, we find an economically and statistically significant impact of value-added first lag on plant-level investment. Furthermore, the price of non-tradable inputs is found to have no significant effect on industrial investment.

\section{Summary and Conclusion}

Investment has important role in the determination of output changes, productivity and growth. Changes in exchange rate can cause large fluctuations in the profitability of production and investment incentives. As Iran had experienced large currency depreciations in the recent years, it can be of great importance to policy makers to understand the exchange rate effects on industry sector performance. In this paper, we used manufacturing annual data of Iran to assess the impact of real exchange rate fluctuations on investment of manufacturing sectors. We used the Iranian data of 2-digits industries from 1995 to 2009 and estimated a dynamic investment equation using panel data model developed by Arellano and Bover (1995) and Blundell and Bond (1998).

It is found a strong negative and statistically significant impact of real exchange rate movements on plant investment. In light of these findings, the analysis incorporates real value-added and the real price of the non-tradable domestic input as control variables in the empirical equation. This avoids omitting potentially important variables, and allows for a comparison of the relative roles of the output, the wage and the exchange rate as determinants of investment.

Since the real exchange rate is indicated as an indicator of competitiveness of domestic goods relative to foreign goods, therefore fluctuations in the exchange rate reduce the desire of producers to invest. The government should try to stabilize the real exchange rate for motivating investment in industry sector. Any change in price index causes the instability of the real exchange rate, so government should implement appropriate policies to reduce the volatility of commodity prices. The foreign exchange reserve is one of the means that the government can use to control exchange rate supply and demand.

\section{References}

Alesina, A., Ardagna, S., Perotti, R., \& Schiantarelli, F. (2002). Fiscal policy, profits, and investment, American Economic Review, 92(3), 571-589. http://dx.doi.org/10.1257/00028280260136255

Arman, S.A., \& Ghorbani, N. (2005). Effect of exchange rate changes on investment in Iran's 
industry subsectors, Journal of Economic Review, 2(4), 5-19.

Arellano, M., \& Bond, S. (1991). Some tests of specification for panel data: Monte Carlo evidence and an application to employment equations, Review of Economic Studies, 58, 277 -297. http://dx.doi.org/10.2307/2297968

Arellano, M., \& Bover, O. (1995). Another look at the instrumental variable estimation of error-components models, Journal of Econometrics, 68, 29-51. http://dx.doi.org/10.1016/0304-4076(94)01642-D

Baldwin, R., \& Krugman, P. (1989). Persistent trade effects of large exchange rate shocks. Quarterly Journal of Economics, 104, 635-654.

Baltagi, B. H. (2001). Econometric analysis of Panel Data. 2d ed. New York: John Wiley\& Sons. http://dx.doi.org/10.2307/2937860

Bernard, A. B., \& Jensen, J. B. (2004). Entry, expansion, and intensity in the U.S. export boom, 1987-1992, Review of International Economics, 12, 662-675. http://dx.doi.org/10.1111/j.1467-9396.2004.00473.x

Blundell, R., \& Bond, S. (1998). Initial conditions and moment restrictions in dynamic panel data models, Journal of Econometrics, 87, 115-143. http://dx.doi.org/10.1016/S0304-4076(98)00009-8

Bodnar, G. M., \& Gentry, W. M. (1993). Exchange rate exposure and industry characteristics: evidence from Canada, Japan and the US, Journal of International Money and Finance, 12, 29-45. http://dx.doi.org/10.1016/0261-5606(93)90008-Y

Bodnar, G. M., Dumas, B., \& Marston, R. C. (1998). Pass-through and Exposure, paper presented at the 1998 American Finance Association meetings in Chicago.

Campa, J., \& Goldberg, L. S. (1995). Investment in manufacturing, exchange rates and external exposure, Journal of International Economics, 38, 297-320. http://dx.doi.org/10.1016/0022-1996(94)01348-V

Campa, J. M., \& Goldberg, L. S. (1999). Investment, pass-through, and exchange rates: a cross-country comparison, International Economic Review, 40(2), 287-314. http://dx.doi.org/10.1111/1468-2354.00016

Choi, I. (2001). Unit root tests for panel data, Journal of International Money and Finance, 20, 249-272. http://dx.doi.org/10.1016/S0261-5606(00)00048-6

Clarida, R. H. (1997). The Real Exchange Rate and US Manufacturing Profits: A Theoretical Framework with Some Empirical Support, International Journal of Finance and Economics, 2, 177-187.

http://dx.doi.org/10.1002/(SICI)1099-1158(199707)2:3<177::AID-IJFE50>3.0.CO;2-U

Feenstra, R. C. (1989). Symmetric pass-through of tariffs and exchange rates under imperfect competition: an empirical test, Journal of International Economics, 27, 25-45. http://dx.doi.org/10.1016/0022-1996(89)90076-7 
Forbes, K. J. (2002a). Cheap labor meets costly capital: the impact of devaluations on commodity firms, Journal of Development Economics, 69, 335-365. http://dx.doi.org/10.1016/S0304-3878(02)00092-5

Forbes, K. J. (2002b). How do large depreciations affect firm performance? IMF Staff Papers, 49, 214-238.

Fuentes, O. (2006). "Exchange Rate Volatility and Investment: Evidence at the Plant-level", mimeo.

Fung, L. (2008). Large real exchange rate movements, firm dynamics, and productivity growth, Canadian Journal of Economics, 41(2), 391-424. http://dx.doi.org/10.1111/j.1365-2966.2008.00468.x

Fung, L., \& Liu, J. T. (2009), The impact of real exchange rate movements on firm performance: A case study of Taiwanese manufacturing firms, Japan and the World Economy, 21, 85-96. http://dx.doi.org/10.1016/j.japwor.2007.11.002

Ghetmiri, M. A. (1996). Measurement and analysis of factors affecting the productivity of Iran's industries, The second of National Congress of productivity.

Goldberg, L. S. (1993). Exchange rates and investment in United States Industry, The Review of Economics and Statistics, 75(4), 575-588. http://dx.doi.org/10.2307/2110011

Hadri, K. (2000). Testing for stationarity inheterogeneous panel data, Econometrics Journal, 3, 148-161. http://dx.doi.org/10.1111/1368-423X.00043

Goldberg P., \& Knetter M. (1997). Good Prices and Exchange Rates: What have we learned, Journal of Economic Literature, 35, 1243-1272.

Harris R. G. (2001). Is There a Case for Exchange Rate Induced Productivity Declines, in L. Schembri (ed.) Re-Visiting the Case for Flexible Exchange Rates, Ottawa, Bank of Canada, 277-309.

Hausmann, R., Pritchett, L., \& Rodrik, D. (2005). Growth Accelerations, Journal of Economic Growth, 10(4), 303-329. http://dx.doi.org/10.1007/s10887-005-4712-0

Head, K., \& Ries, J. (1999). Rationalization effects of tariff reductions, Journal of International Economics, 47, 295-320. http://dx.doi.org/10.1016/S0022-1996(98)00019-1

Im, K. S., Pesaran, M. H., \& Shin, Y. (2003).Testing for unit roots in heterogeneous panels. Journal of Econometrics, 115, 53-74. http://dx.doi.org/10.1016/S0304-4076(03)00092-7

Jorion, P. (1990). The exchange-rate exposure of US multinationals, Journal of Business, 63, 331-45. http://dx.doi.org/10.1086/296510

Kandilov, T., \& Leblebicioğlu, A. (2011). The impact of exchange rate volatility on plant-level investment: Evidence from Colombia, Journal of Development Economics, 94, 220-230. http://dx.doi.org/10.1016/j.jdeveco.2010.01.013

Khodaparast, J. (2001). Comparison Investigation of total productivity of production factors in 


\section{Macrothink}

Business and Economic Research

ISSN 2162-4860

2013, Vol. 3, No. 2

large industries, Management and Planning Organization of Fars Province, Coordination and Planning Department.

Krugman, P. (1979). Increasing returns, monopolistic competition, and international trade, $\begin{array}{lllll}\text { Journal of International } & \text { Economics, } & 9, & 469-479 .\end{array}$ http://dx.doi.org/10.1016/0022-1996(79)90017-5

Landon, S., \& Smith, C. E. (2007). The exchange rate and machinery and equipment imports: identifying the impact of import source and export destination country currency valuation changes, North American Journal of Economics and Finance, 18, 3-21. http://dx.doi.org/10.1016/j.najef.2006.08.001

Levin, A., Lin, C. F., \& Chu, C. (2002). Unit root tests in panel data: asymptotic and finite-sample properties, Journal of Econometrics, 108, 1-24. http://dx.doi.org/10.1016/j.najef.2006.08.001

Lotfalipour M. R., \& Razmara, A. (2006). Evaluation of Technical Efficiency and Productivity Trend in Iran's Industry(Case Study of Fifty and More Employee Firms), Knowledge and Development, 18, 55-78.

Maddala, G. S., \& Wu, S. (1999). A comparative study of unit root tests with panel data and a new simple test, Oxford Bulletin of Economics and Statistics, 61, 631-652. http://dx.doi.org/10.1016/j.najef.2006.08.001

Nouira, R., Plane, P., \& Sekkat, K. (2011). Exchange rate undervaluation and manufactured exports: A deliberate strategy?, Journal of Comparative Economics, 39, 584-601. http://dx.doi.org/10.1016/j.jce.2011.08.002

Serven, L. (2003). Real exchange rate uncertainty and private investment in developing countries, Review of Economics and Statistics, 85(1), 212-217. http://dx.doi.org/10.1162/rest.2003.85.1.212

Stuart Landon, S., \& Smith, C. E. (2009). Investment and the exchange rate: Short run and long run aggregate and sector-level estimates, Journal of International Money and Finance, 28, 813-835. http://dx.doi.org/10.1016/j.jimonfin.2008.07.009

\section{Copyright Disclaimer}

Copyright reserved by the author(s).

This article is an open-access article distributed under the terms and conditions of the Creative Commons Attribution license (http://creativecommons.org/licenses/by/3.0/). 